\title{
Argonaute and Argonaute-Bound Small RNAs in Stem Cells
}

\author{
Lihong Zhai ${ }^{1,+}$, Lin Wang ${ }^{2,+}$, Feng Teng ${ }^{1}$, Lanting Zhou ${ }^{1}$, Wenjing Zhang ${ }^{1}$, Juan Xiao ${ }^{1}$, \\ Ying Liu ${ }^{3,4, *}$ and Wenbin Deng ${ }^{5,6, *}$ \\ 1 Medical College, Hubei University of Arts and Science, Xiangyang 441053, Hubei, China; \\ zhailihong@webmail.hzau.edu.cn (L.Z.); tengfeng1217@webmail.hzau.cn (F.T.); \\ lanting_zhou@yeah.net (L.Z.); starking521@webmail.hzau.edu.cn (W.Z.); xiaojuan@bjmu.edu.cn (J.X.) \\ 2 Xiangyang Oral Hospital, Xiangyang 441003, Hubei, China; tobenumberone@yeah.net \\ 3 Department of Neurosurgery, Medical School, the Brown Foundation Institute of Molecular Medicine for the \\ Prevention of Human Diseases, University of Texas Health Science Center at Houston, Houston, \\ TX 77030, USA \\ 4 Center for Stem Cell and Regenerative Medicine, the Brown Foundation Institute of Molecular Medicine for \\ the Prevention of Human Diseases, University of Texas Health Science Center at Houston, Houston, \\ TX 77030, USA \\ 5 Department of Biochemistry and Molecular Medicine, School of Medicine, University of California, Davis, \\ CA 95817, USA \\ 6 Institute for Pediatric Regenerative Medicine, Shriners Hospitals for Children, Sacramento, CA 95817, USA \\ * Correspondence: Ying.Liu@uth.tmc.edu (Y.L.); wbdeng@ucdavis.edu (W.D.); \\ Tel.: +1-713-500-3567 (Y.L.); +1-916-453-2287 (W.D.); Fax: +1-713-500-2424 (Y.L.); +1-916-453-2288 (W.D.) \\ + These authors contributed equally to this work.
}

Academic Editor: Cesar Borlongan

Received: 24 December 2015; Accepted: 1 February 2016; Published: 4 February 2016

\begin{abstract}
Small RNAs are essential for a variety of cellular functions. Argonaute (AGO) proteins are associated with all of the different classes of small RNAs, and are indispensable in small RNA-mediated regulatory pathways. AGO proteins have been identified in various types of stem cells in diverse species from plants and animals. This review article highlights recent progress on how AGO proteins and AGO-bound small RNAs regulate the self-renewal and differentiation of distinct stem cell types, including pluripotent, germline, somatic, and cancer stem cells.
\end{abstract}

Keywords: Argonaute; Piwi; small RNAs; stem cells

\section{Introduction}

Small RNAs, including microRNAs (miRNAs), short interfering RNAs (siRNAs) and Piwi-interacting RNAs (piRNAs), achieve their gene silencing functions at diverse levels of cellular progresses, including at the transcription, RNA processing, RNA stability, translation and post-translational levels [1,2]. These small RNAs execute their effects by associating with Argonaute (AGO) proteins, which are further divided into three subfamilies, AGO, Piwi, and Group 3 (known as WAGO) subfamilies. The miRNAs and siRNAs interact with AGOs, while piRNAs mainly interact with Piwi. Since Group 3 (WAGO) subfamily is only found in worms, we focus on AGO and Piwi in this review. Both protein subfamilies are found in a range of stem cell types and have important roles in a variety of cellular functions, including stem cell maturation and differentiation, embryonic development, and transposon functions [3], which critically contribute to the regulation of self-renewal, proliferation and differentiation of stem cells via specific mechanisms [4-7]. This concise review provides an update on recent progress regarding AGO and AGO-bound small RNAs and their regulation of various types of stem cells, such as pluripotent, germline, somatic, and cancer stem cells. 


\section{The Argonaute (AGO) Family}

The AGO protein family was first identified in plants. The term AGO was derived from ago1 in Arabidopsis [8]. Shortly after the identification of ago1, several additional AGO proteins were discovered in numerous organisms for their function in small RNA-directed silencing [9]. According to their functional domains, AGO proteins are subdivided into AGO proteins (the AGO clade) and Piwi proteins (the Piwi clade) [10] (Table 1). A prototype member of the AGO clade is Arabidopsis thaliana AGO1, while all Piwi proteins, share significant homology to Drosophila melanogaster Piwi [11]. AGO proteins function by cooperating with miRNAs or siRNAs and regulate gene-silencing at thepost-transcriptional level. Piwi proteins act by binding to piRNAs and exert their function through silencing of transposable elements [11-13]. Group 3 subfamily is only found in worms (Caenorhabditis elegans, known as WAGO), while AGO and Piwi subfamilies are found in a variety of species, such as plants, yeasts, flies, and mammals. The number of AGO proteins varies among different species, the fission yeast (Schizosaccharomyces pombe) has only one AGO protein, while the nematode worm has 27 different AGO proteins. However, the structure of AGO proteins is highly conserved. In the mouse, eight AGO proteins are categorized into two subfamilies: five to the AGO subfamily (simplified as AGO-like) and the remaining three to the Piwi subfamily. Similarly, in human, based on NCBI's sequence alignment, four AGO proteins ( $h A G O 1 / E I F 2 C 1, h A G O 2 / E I F 2 C 2$, $h A G O 3 / E I F 2 C 3$, and $h A G O 4 / E I F 2 C 4$ ) and four Piwi proteins (Hiwi/Piwil1, Hili/Piwil2, Piwil3, and Hiwi2/Piwil4) [14] have been identified. Previous expression profiling in mammalian cells revealed that the expression of AGO subfamily members can be found in all tissues ubiquitously, whereas expression of the Piwi proteins seems to be restricted to germ cells [4]. Recent reports, however, have recognized somatic Piwi as well [15]. A complete tissue array of the various AGO proteins in different tissues will provide a comprehensive gene expression profile. Such work may offer clues to reveal potential novel functions of AGO proteins.

AGO proteins are large proteins and have a molecular weight of approximately $100 \mathrm{kDa}$. Regardless of the subfamilies, they usually contain one variable N-terminal domain, PAZ (Piwi-Argonaute-Zwille), MID (middle) and Piwi domains (Figure 1) [3]. The variable N-terminal region is reported to facilitate the separation of the small RNA: target duplex [9]. PAZ domain composes a particular binding module that anchors the 2-nt $3^{\prime}$ overhangs of small RNAs [3], which is critical for dsRNA processing in RNAi, as revealed by X-ray crystallography. The MID domain binds $5^{\prime}$ phosphates of small RNAs by a highly basic pocket, serving as an anchor of small RNAs onto AGO proteins $[16,17]$. Another function of the MID domain is to repress translation through a motif similar to eIF4E [18]. The Piwi domain contains a DDX (where X is D or H) motif, a catalytic triad DDX, which is homologous to RNase $\mathrm{H}$ enzymes and renders endonuclease activity for AGO proteins $[19,20]$ (Figure 1). However, a DDX motif does not necessarily guarantee slicer activity [10] and only a subset of AGO proteins can cleave [11]. In the budding yeast Kluyveromyces polysporus, it seems that a constant glutamic acid (E) residue has to be tagged into the catalytic pocket to create a DEDD or DEDH tetrad for slicing activity [21]. In human, endonuclease activity of AGO2 might come from several aspects: the Piwi domain, a loop in the $\mathrm{N}$ terminal domain, and possibly unidentified AGO2 binding partners [22]. The 2.3 angstrom resolution crystal structure of human AGO2 has revealed that all the characteristic AGO domains are conserved in human AGO2, and that the interaction sites (tryptophan-binding pockets) in the Piwi domain for binding GW motif also exist [23]. QF-V motif of Piwi domain recognizes base-paring at the 15th base of a miRNA duplex, whereas recognition of the central nucleotides is critically dependent upon the DDDE catalytic core of AtAGO2 [24]. In addition to domains related to endonuclease activities, AGO protein motifs for small RNA sorting and protein-protein interactions have also been characterized in more depth. For instance, MID domain of human $\mathrm{AGO} 2$ has been reported to interact with fragile $\mathrm{X}$ mental retardation protein (FMRP) via a specific binding pocket composed of one tyrosine and two lysine residues, FMRP subsequently associates with miR-196a to silence HOXB8 mRNA [25]. Therefore, MID domain in AGO2 is critical for miR-196's silencing effect toward HOXB8. Human AGO2 might also function as a framework by 
binding to guide RNA and target RNA duplex formed by pairing of miRNAs and the complementary target RNAs [26]. Another function of human AGO2 is to interact with A nucleotides through the water-mediated interaction of t1-nucleotide binding pocket and adenosine N6 amine, ensuring fixation of target RNAs on AGO2 [24,27].

A

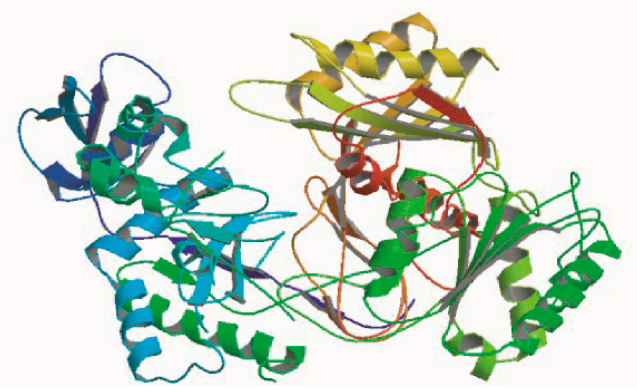

B

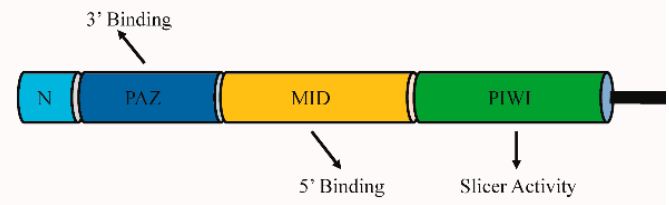

Figure 1. Domain schematics of a typical Argonaute protein. (A) Crystal structure of Aquifex aeolicus Argonaute (adapted from PDB database, PDB ID: 2NUB) [28], with stereo-view ribbon illustration of Argonaute showing the N-terminal domain (light blue), the PAZ domain (blue), the MID domain (yellow), the Piwi domain (green); (B) Schematic depiction of the Argonaute domain. PAZ domain anchors the characteristic 2-nt 3' overhangs of small RNAs. The MID domain binds 5' phosphates of small RNAs, and functions as an anchor of small RNAs binding to the Argonaute (AGO) protein. Piwi domain is an RNase H domain.

Table 1. Characterized Argonaute (AGO) proteins in different species.

\begin{tabular}{|c|c|c|c|}
\hline Gene Name(Subfamily) & Molecular Function & sRNA Bound & Reference \\
\hline \multicolumn{4}{|c|}{ Homo sapiens } \\
\hline EIF2C1/hAGO1 (AGO) & $\begin{array}{l}\text { miRNA-directed target gene regulation, } \\
\text { constitutive and alternative splicing, } \\
\text { heterochromatin silencing }\end{array}$ & miRNAs & [29-31] \\
\hline EIF2C2/hAGO2 (AGO) & $\begin{array}{l}\text { miRNA-directed target gene regulation, } \\
\text { heterochromatin silencing, RNAi }\end{array}$ & miRNAs, siRNA & [30-32] \\
\hline EIF2C3/hAGO3 (AGO) & miRNA-directed target gene regulation & miRNAs & [30] \\
\hline EIF2C4/hAGO4 (AGO) & miRNA-directed target gene regulation & miRNAs & [22] \\
\hline Piwil1 / Hiwi (Piwi) & $\begin{array}{l}\text { stem cell self-renewal, division, } \\
\text { gametogenesis, germ cell proliferation, and } \\
\text { RNAi }\end{array}$ & piRNAs & {$[3,12]$} \\
\hline Piwil2/Hili (Piwi) & signaling regulation & piRNAs & [33] \\
\hline Piwil3 (Piwi) & $\mathrm{n} / \mathrm{d}$ & piRNAs & {$[3,12]$} \\
\hline Piwil4/Hiwi2 (Piwi) & transposon silencing & piRNAs & [34] \\
\hline \multicolumn{4}{|c|}{ Drosophila melanogaster } \\
\hline dAGO1 (AGO) & miRNA-mediated gene silencing & 22-23-nt miRNAs & {$[35,36]$} \\
\hline dAGO2 (AGO) & RNAi in embryos & $\begin{array}{l}\text { miRNAs and 21-nt } \\
\text { siRNAs }\end{array}$ & [35-38] \\
\hline dAGO3 (Piwi) & transposon silencing & piRNAs & [39-41] \\
\hline Aubergine/AUB (Piwi) & $\begin{array}{l}\text { transposon silencing, stellate silencing, } \\
\text { RNAi }\end{array}$ & piRNAs & {$[41,42]$} \\
\hline Piwi (Piwi) & $\begin{array}{l}\text { transposon silencing, germline stem-cell } \\
\text { maintenance, RNAi }\end{array}$ & piRNAs, rasiRNAs & [41-43] \\
\hline
\end{tabular}


Table 1. Cont.

\begin{tabular}{|c|c|c|c|}
\hline Gene Name(Subfamily) & Molecular Function & sRNA Bound & Reference \\
\hline \multicolumn{4}{|c|}{ Arabidopsis thaliana } \\
\hline AtAGO1 & $\begin{array}{l}\text { plant development regulation and } \\
\text { stress responses }\end{array}$ & 21-nt miRNAs & {$[8,44,45]$} \\
\hline AtAGO2 & $\begin{array}{l}\text { antibacterial immunity, viral defense, } \\
\text { DSB-induced sRNAs activity, } \\
\text { and DNA repair }\end{array}$ & $\begin{array}{l}\text { 21-nt miRNAs, } \\
\text { vsiRNAs, diRNAs }\end{array}$ & [46-48] \\
\hline AtAGO3 & $\mathrm{n} / \mathrm{d}$ & $\mathrm{n} / \mathrm{d}$ & \\
\hline AtAGO4 & RdDM pathway & 24-nt siRNAs & {$[49,50]$} \\
\hline AtAGO5 & $\begin{array}{l}\text { initiation of megagametogenesis, antiviral } \\
\text { RNA silencing }\end{array}$ & siRNAs & {$[46,51-53]$} \\
\hline AtAGO6 & $\begin{array}{l}\text { methylation of tasiRNA-generating loci and } \\
\text { transcriptionally active TEs, shoot and root } \\
\text { meristems }\end{array}$ & $\begin{array}{l}\text { 24-nt siRNAs, } \\
\text { 21-22-nt } \\
\text { endo-siRNAs }\end{array}$ & {$[49,54-56]$} \\
\hline AtAGO7/ZIPPY & $\begin{array}{l}\text { TAS3-derived tasiRNA biogenesis, } \\
\text { leaf development }\end{array}$ & $\operatorname{miR} 390$ & [57] \\
\hline AtAGO8 & Proposed to be a pseudogene & $\mathrm{n} / \mathrm{d}$ & [10] \\
\hline AtAGO9 & $\begin{array}{l}\text { germ cell fate repression in the somatic } \\
\text { companion cells surrounding MMC, and } \\
\text { DNA repair }\end{array}$ & 24-siRNAs & {$[46,58]$} \\
\hline $\begin{array}{l}\text { AtAGO10/PINHEAD/ } \\
\text { ZWILLE }\end{array}$ & regulation of shoot apical meristems & $\begin{array}{l}\operatorname{miR} 165 / 166 \\
\operatorname{miR} 172\end{array}$ & [59-63] \\
\hline \multicolumn{4}{|c|}{ Oryza sativa } \\
\hline OsAGO1a/b/c & miRNA-directed target gene regulation & 21-nt miRNAs & [64] \\
\hline OsAGO5c/MEL1 & $\begin{array}{l}\text { regulation of cell division of premeiotic } \\
\text { germ cells }\end{array}$ & 21-nt siRNAs & {$[65,66]$} \\
\hline OsAGO7 & TAS3-derived tasiRNA biogenesis & $\operatorname{miR} 390$ & [67] \\
\hline OsAGO10/OsPNH1 & $\begin{array}{l}\text { regulates leaf development and } \\
\text { maintenance of the shoot apical meristem }\end{array}$ & $\mathrm{n} / \mathrm{d}$ & [68] \\
\hline OsAGO18 & broad-spectrum virus resistance & $\mathrm{n} / \mathrm{d}$ & [69] \\
\hline \multicolumn{4}{|c|}{ Zea mays } \\
\hline ZmAGO7/RGD2 & TAS3-derived tasiRNA biogenesis & $\operatorname{miR} 390$ & [70] \\
\hline ZmAGO9/AGO104 & somatic cell fate repression in the germ cells & $\mathrm{n} / \mathrm{d}$ & [71] \\
\hline ZmAGO18b & tapetum and germ cell development & $\mathrm{n} / \mathrm{d}$ & [72] \\
\hline
\end{tabular}

\section{The Association of AGO Proteins and Small RNAs}

RISC (RNA-induced silencing complexes). AGO proteins recruit specific small RNAs to form RISCs, which target specific sequences in RNA or DNA in the genome (Figure 2). All types of described small RNAs (namely miRNA, siRNA, and piRNA) are known to associate with AGO and/or Piwi proteins to form RISCs [73]. Small RNAs in RISCs serve as guides for AGOs, which execute enzyme functions at specific locations. Interestingly, to perform their effector functions, small RNAs must be incorporated into AGO-protein containing complexes [74,75]. Otherwise, they would be degraded rapidly in cells. Depending on the subcellular locations and AGO proteins associated within the complex, different RISCs will cause cleavage of target mRNAs, inhibit translations, or perform chromatin modification of target genes [76] (Figure 2). In miRNA pathway, only the guide strand of small RNAs will base-pair with the target mRNA and is retained, while the passenger strand is disposed and degraded [1]. Similarly, during the canonical siRNA pathway, RISC is brought to RNA targets by the siRNA guide strand, and the Piwi domain of the AGO proteins is responsible for precisely slicing target RNAs. Piwi domain cleaves at the phosphodiester bond at No. 10 and 11 nucleotides. 
The cleaved products will have $5^{\prime}$-monophosphate and $3^{\prime}$-hydroxyl termini [77]. In the case of an imperfect matching of siRNA and its target, two additional mechanisms are at work to silence the gene. One is through the posttranscriptional level, such as translational repression. The other is transcription gene silencing (TGS) by siRISCs via histone $\mathrm{H} 3$ or DNA methylation [1]. In addition to functioning in gene silencing, it is reported that Arabidopsis AGOs AtAGO2 and AtAGO9 might participate in DNA repair, although detailed mechanism of action remains to be unraveled [46].

Piwi and piRNAs. piRNAs are noncoding RNAs that bind Piwi proteins. Distinct from miRNAs and siRNAs, piRNAs have a length of 26-31 nt. piRNAs precursors are single stranded and are generated from repetitive sequences in the genome. Biogenesis and stability of piRNA might rely on Piwi proteins [18], as illustrated in the so-called "Ping-Pong" model (Figure 3), in which Piwi proteins cooperate in secondary piRNA production. piRNA-Piwi complexes also play important roles in maintaining genome integrity by preventing excessive transposon mobilization [78], which contributes to genome instability by replicating and/or inserting into new genomic locations. piRNA-Piwi complexes are proposed to act at various levels to control transposon activity: (1) At the post-transcription level, by destructing mRNA transcripts in the cytoplasm, one example is MIWI-piRNA, which functions in the mouse germline cells [43,79]. Another example is the regulation of maternal mRNA by piRNA and a newly identified Piwi protein, Aubergine (AUB) [80]; (2) at the transcription level, piRNA-Piwi interferes with heterochromatin assembly, which results in transcriptional silencing [81-83]; (3) at the translation level, piRNA-Piwi interacts with translation initiation factors, a classical example of which is the interaction of MILI, a mouse Piwi protein, with eIF3a and eIF4G [5]. In addition, piRNAs might regulate gene expression independent of Piwi proteins. For example, piR-55490 is reported to be able to bind mTOR mRNA directly and to induce its degradation [84].

Construction of AGO-small RNA target network. Although sharing similar functional domains, apparently AGO proteins have their own preference in choosing small RNA binding partners. Traditionally, quantitative real-time PCR, degradome sequencing and 5' RLM-RACE (RNA Ligase Mediated Rapid Amplification of cDNA Ends), have been used in predicting AGO and small RNA target pairs [85-87]. The development of high-throughput sequencing allows for global profiling of RNAs isolated from immunopurification (RIP-seq) and by crosslinking and immunoprecipitation (CLIP-seq or HITS-CLIP), paving the way to identification of AGO protein-small RNA-mRNA interaction sites in both plants and animals [20,52,88-91]. Computational prediction of small RNA targets relies on a combinatorial approach. Rules frequently are derived from previously validated binding partners, and in silico prediction is usually the first step of providing clues of candidates for AGO and small RNA binding partners. Indeed, identification of the small RNAs sorting into the appropriate AGO proteins is a prerequisite for elucidating a small RNA's function. Several observations have been made: (1) the size of small RNAs. Different Arabidopsis AGO (AtAGO) proteins bind small RNAs with distinct sizes. AtAGO1 or AtAGO2 is found to form complexes with small RNAs of $21 \mathrm{nt}$ long, AtAGO4 and AtAGO9 with small RNAs of $24 \mathrm{nt}$ in size. AtAGO5 is less selective as it binds small RNAs in the length of 21, 22 or $24 \mathrm{nt}$; (2) chemical composition/modification of termini. AtAGO1 binds small RNAs with a uridine at 5', AtAGO2, AtAGO4 prefers small RNAs with an adenosine at $5^{\prime}$, and AtAGO5 binds small RNAs with a cytosine at $5^{\prime}$ [52]. AtAGO7 is more biased in choosing small RNAs and only forms interactions with miR390 [92]; (3) origin (precursors) of small RNAs. A good example is that AtAGO9 preferentially forms complexes with small RNAs derived from transposable elements (TEs) [93]. These observations have facilitated the development of protocols and computational algorithms for identification of AGO-small RNA network in higher organisms including mammals and humans. Additional more advanced approaches have also been developed. For instance, high-throughput sequencing of RNA extracted from crosslinking immunoprecipitation (HITS-CLIP) using highly selective monoclonal antibodies have identified additional AGO binding partners. In mouse testes, MIWI- and MILI-associated piRNAs are determined to be 29-31 or 26-28 nt in length, respectively [94,95], confirming the predicted sites from different computer algorithms [96], offering 
increased confidence in conducting AGO HITS-CLIP in other organisms $[88,91,97,98]$. CLIP-seq of AGO2 in mouse ESCs revealed that GCACUU motif in $3^{\prime}$ UTRs and CDS correspond to miRNA seed matches [99]. Recently, a study of analyzing 34 AGO HITS-CLIP datasets observed that in different cell types, miRNA targets show distinct distribution patterns in the genomes, while in same cell types, the distributions are also identical [100]. Elucidation of AGO-small RNAs-targets network with HITS-CLIP in specific tissues or cells is revealing the regulatory mechanism of small RNAs.

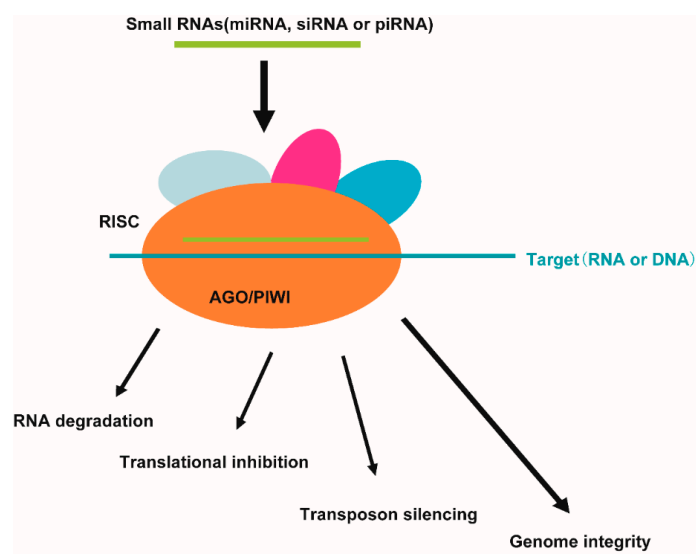

Figure 2. Guiding small RNAs' gene silencing functions by AGO proteins.

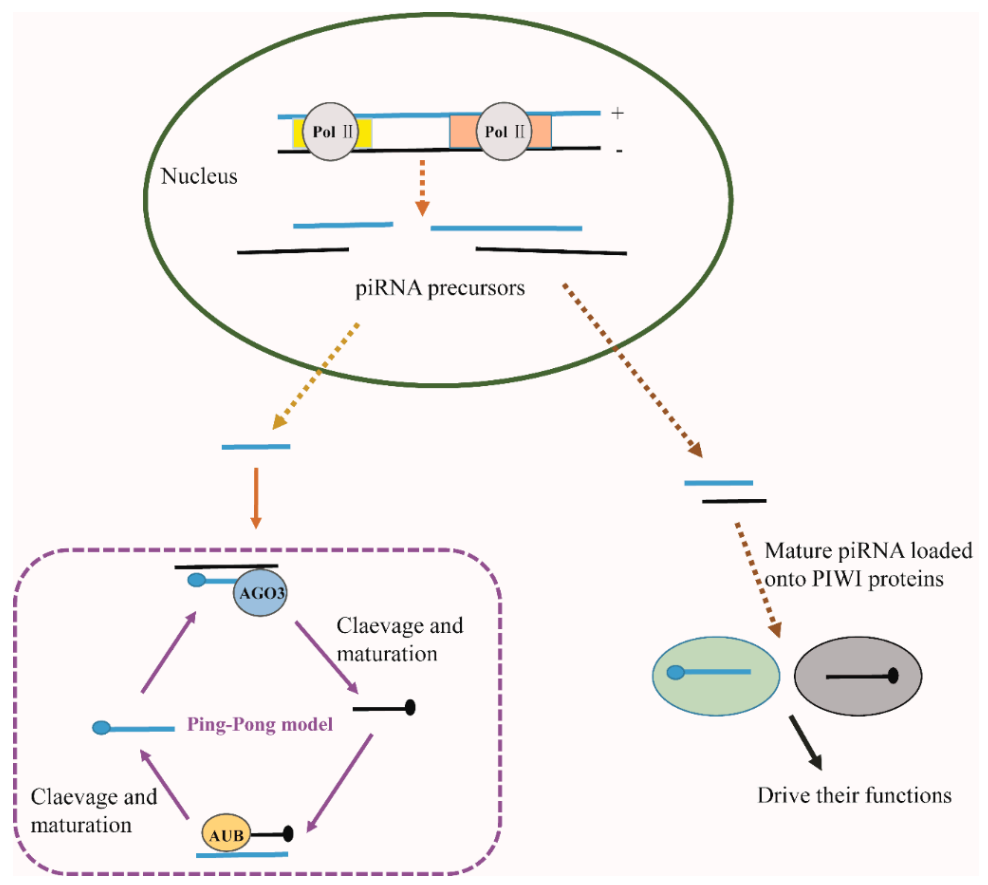

Figure 3. Biogenesis of piRNAs and the "Ping-Pong" model in D. melenogaster. piRNA clusters in the genome can be transcribed in either direction, sense or antisense. The long single-stranded RNA is the basis for piRNA generation. In D. melanogaster, to create sense and antisense piRNAs, Aubergine (AUB) and Ago3 two Piwi proteins, partner in secondary piRNA production. AGO3 only associates to piRNAs that are generated from retrotransposons' sense strand. On the contrary, AUB mainly binds piRNAs made from the antisense strand. This phenomenon leads to the "Ping-Pong" model. Based on "Ping-Pong" model, AGO3-piRNA complex induced cleavage specifies the 5'-end of AUB-associated piRNAs, the AUB-piRNA complex then generates the 5'-end of AGO3-bound piRNAs. Mature piRNAs are loaded onto Piwi proteins and guide them to transposable elements derived complementary RNAs. Piwi proteins slice the transposon RNA to induce silencing in a similar fashion to RNAi. 


\section{Argonaute-Interacting Partners and Regulation of Argonaute Function}

AGO-interacting proteins. Argonautes participate in many maturation processes of small RNAs as well as gene repression pathways that are mediated by small-RNAs, which involve interactions with diverse protein complexes. During miRNA-directed mRNA inhibition, the N-terminal domain of GW182 proteins, which contains multiple bi amino acid repeats of glycine-tryptophan (GW), that binds to AGO proteins. Such binding is necessary to facilitate all downstream gene silencing effects [101]. The C-terminal part of GW182, on the other hand, interacts with the poly (A)-binding protein on the poly (A) tail of the mRNA. In addition, direct interactions of the C-terminal part with PAN2/3 and the CCR4/NOT complex, which are cellular deadenylases, deadenylate the mRNA. Subsequently, the mRNA is decapped by DCAP1/2 and then degraded by the exonuclease XRN1 [102-105]. To make the process even more complex, other proteins also participate and regulate at additional levels. For instance, Pumilio (Pum) protein regulates the efficiency of miRNA-directed gene silencing [106], impotin8 (IPO8) or UPF1 maintains target association of AGO complexes [107,108], and UBR5 facilitates in recruiting downstream factors by associating with GW proteins [109]. There also have been reported some proteins interacting with Piwi-piRNA complexes. For example, protein arginine $\mathrm{N}$-methyltransferase 5 (PRMT5), Tudor-domain-containing proteins (TDRDs) Tudor domain proteins Tud, spindle E (SpnE), krimper (Krimp), female sterile (1) Yb ( $\mathrm{Fs}(1) \mathrm{Yb})$, tejas (Tej), vreteno (Vret), etc. However, the molecular mechanisms remain to be revealed [11]. Recently, CG9754/Silencio has been found to be an essential factor for Piwi-mediated transcriptional silencing in Dropsophila during heterochromatin formation [110].

Regulation of AGO function. Similar to majority genes, gene expression of AGO is also regulated at several levels. For example, AtAGO1 mRNA is found to be the target of miRNA168 and this process is needed for proper plant development, exemplifying the importance of feedback control by miRNA [44]. Similarly, the expression of human AGO2 was inhibited by miR-132 during primary cell activation [111], on the contrary, miR346 enhanced the expression of AGO2, leading to the increased activity of other miRNAs and contributing to the malignancy of Hela cells [112]. In addition to small-RNA directed gene silencing, ubiquitylation and phosphorylation were also identified to control the expression of AGO proteins [11].

\section{AGO Proteins and AGO-Bound Small RNAs in Stem Cells}

AGO proteins and AGO-bound small RNAs are identified in various types of stem cells [113] in diverse species ranging from plants and animals (Figure 4). The AGO family was first identified to be essential for stem cell maintenance in lower organisms, such as Drosophila, C. elegans, and Arabidopsis [114], as knocking out AGO proteins decreases the number of stem cells or abolishes normal development [4]. To date, all three AGO subfamilies have been reported to function in various stem cell types, including germline and non-germline stem cells, normal and malignant stem cells, and pluripotent and somatic stem cells. Here, we emphasize the expression and function of the AGO/Piwi family in plant stem cells, germline stem cells, pluripotent stem cells (including embryonic stem cells andinduced pluripotent stem cells), somatic stem cells (including hematopoietic stem cells and mesenchymal stem cells), as well as cancer stem cells.

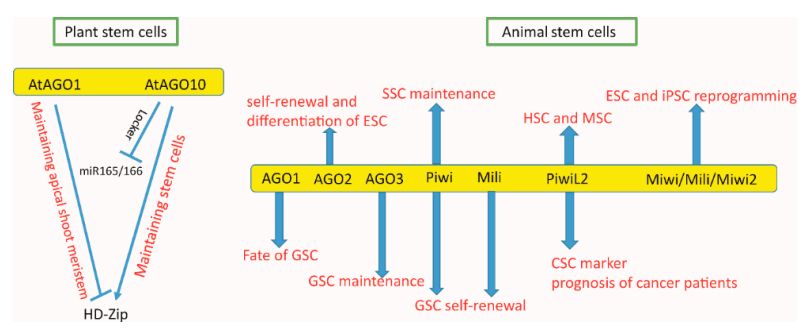

Figure 4. Summary of Argonaute proteins function in various stem cells. 
Plant stem cells. Plant stem cells are found at the tips of roots, shoots, and developing flowers. Stem cells located at different organs of a plant have distinct functions. The above-ground portion of the plant is derived from the stem cells in the shoot apical meristem (SAM) [63]. The stem cells from the meristem are committed to becoming a single central organ of the plant [4]. Loss of function mutation of AtAGO1 (named for Arabidopsis AGO, or PINHEAD/ZWILLE in mammals), exhibits phenotypes of both abnormal axillary meristems and leaf formation, indicating that AtAGO1 is essential in SAM function [8]. On the other hand, AtAGO10 (PINHEAD/ZWILLE) is required for shoot meristem formation via self-perpetuating shoot meristem divisions [59]. Apparently AtAGO1 and AtAGO10 have functional redundancy because only double mutants demonstrate impaired SAM initiation and maintenance, which act through a pathway that is regulated by SHOOT MERISTEMLESS, a homeobox transcription factor [60]. However, AtAGO1 and AtAGO10 act via distinct mechanisms. AtAGO1 mainly functions through associating with miRNAs and siRNAs, and its effector complexes cleave mRNAs via slicer activity [115]. However, AtAGO10 exerts regulatory functions through miRNA-mediated translational repression [116]. It appears that AtAGO1 and AtAGO10 are both important in stem cells' temporal control. Both AGO proteins repress AP2 and HD-Zip through miRNA miR172 and miR165/166, It is interesting to note that AtAGO1 and AtAGO10 function in opposite ways both in accumulation of miR165/166 and in controlling the gene expression of HD-Zip genes. In ago10 mutants, the expression of miR165/166 is increased and the expression of HD-Zip genes is decreased. This suggests that AGO10 upregulates HD-Zip expression via decreasing miR165/166 levels by acting as a locker for miR165/166. Interestingly, AGO1 and AGO10 do not always function in different directions as in HD-Zip gene expression regulation, and they actually both boost floral determinacy. One possible explanation is that up- and down-regulation of different HD-Zip genes are involved in floral determinacy $[62,63]$.

Germline stem cells. Drosophila Piwi family member, Piwi, is expressed in both the germline and soma. Piwi is essential for self-renewal and asymmetric division GSCs [114]. Both male and female Piwi mutant flies are infertile, are depleted of GSCs, and their gonads contain only significantly lower number of egg chambers or sperm bundles. Piwi maintains GSCs and controls their differentiation in both cell-autonomous and non-cell-autonomous manners [114]. Somatic Piwi provides a niche to GSCs by upregulating decapentaplegic (Dpp) pathway [117,118]. Piwi also interacts with Corto, a gene encodes a chromatin protein, which controls Piwi expression in niche cells to maintain GSCs through an epigenetic mechanism. On the other hand, loss of Piwi also causes GSC-like tumors that persist throughout adult life and defects in intermingled cells (ICs), the progenitor cells of escort cells and escort cells, causing ectopic Dpp signaling and subsequent prevention of GSC differentiation [118]. Previous research has shown that Drosophila Piwi functions on genome stability maintenance in the germline. Piwi silences transposable elements (TEs) by recruiting 26-32 nt piRNAs [119]. However, more recent data from a Piwi ${ }^{N t}$ mutation, which is devoid of the nuclear localization signal (NLS), show that female flies could maintain self-renewal of the GSCs. The number of egg chambers is not affected either. The only phenotype is the derepression of transposable elements (TE) and nuclear accumulation of their mRNAs in the germ line. These results indicate that Piwi controls self-renewal of GSCs via GSC niche cells but not through manipulating TE function [120] (Figure 5). In parallel, Piwi may contribute to the differentiation of GSCs via escort cells (ECs) [121]. In addition, Piwi also interacts with Fasciclin 3, a gene essential for somatic cyst cells in gonadal development, in a cell-autonomous fashion. Such interaction has added a novel layer of Piwi regulation in GSCs [15]. Not only Piwi, but also Ago1 in Drosophila plays indispensable roles in regulating GSC fate. Overexpression of Ago1 causes GSCs over-proliferation, whereas Ago1 knockout results in GSC depletion. Unlike Piwi, AGO1, although also plays a role in GSC fate regulation, does not act upstream of "bag of marbles" (bam) and is dispensable for bam silencing. Current data indicates that AGO1 might function either downstream of bam or in parallel with bam [122]. In ago3 mutant flies, GSCs are not properly maintained, thus causing reduced fertility [123]. 


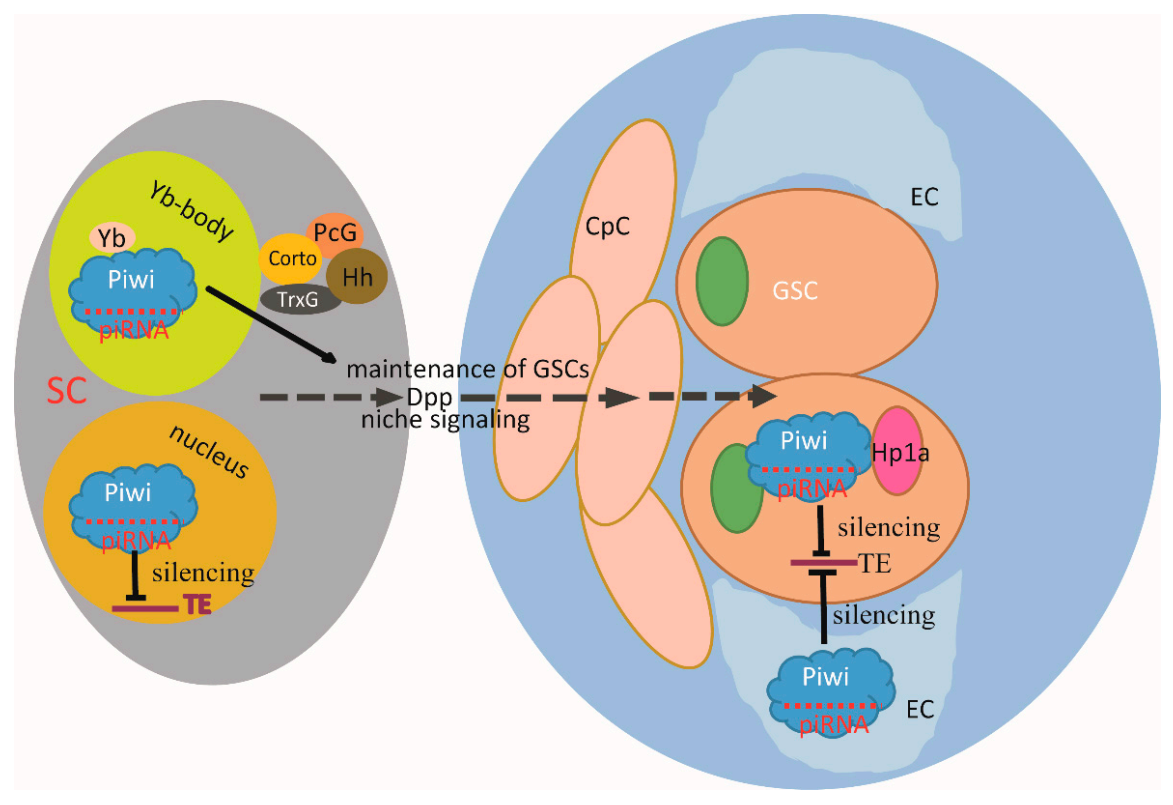

Figure 5. Piwi function in Drosophila GSCs self-renewal. Stem cell self-renewal requires both cell-autonomous and extrinsic signaling mechanisms. Niche signaling pathways involving Yb, Piwi, Dpp and Hh are expressed in SCs for GSC maintenance. The chromatin factor Corto, which is expressed in the niche cells, interacts with Piwi, PcG and TrxG in epigenetic regulation. Piwi also interacts with HP1a for TEs silencing for GSCs self-renewal. Piwi in ECs maintains PGC and GSC germlines and controls GSC lineage differentiation. Dpp: Decapentaplegic; Hh: Hedgehog; SCs: Somatic Cells; GSC: Germ Stem Cell; PcG: Polycomb group; TrxG: Trithorax group; HP1a: Heterochromatin protein 1a. TEs: Transposable elements; ECs: Escort cells; PGC: Primordial germ cell.

Mice have three Piwi proteins, Mili (PiwiL2), Miwi, and Miwi2, all of which are essential for spermatogenesis. Mili is detected in the cytoplasm of spermatogonia, testicular GSCs, and chromatoid bodies of early spermatocytes it is. Mili loss-of-function mutants show failure of self-renewal and differentiation of GSCs. However, the primary germ line stem cell population is not affected. Interestingly, Mili mutation decreases the turnover of protein synthesis of stem cell specific genes although does not function at the mRNA transcripts, suggesting a function of Mili in promoting GSC division and differentiation via translational regulation [5].

Cancer stem cells. Cancer stem cells (CSCs) are regarded as a sustainable source of malignant cells. These cells, though constitute an extremely low proportion of the total tumor cells, may serve as the culprit contributing to drug resistance, tumor recurrence, metastasis and progression [124]. Similar to other types of stem cells, CSCs self-renew and have the capacity to differentiate. Several Piwi family members have been found in different types of cancers. For example, PiwiL2 is expressed in precancerous stem cells and breast cancers. PiwiL2 expression levels correlate with breast stages and is a good candidate for diagnostic marker [125] and a therapeutic target [126]. Mili also is expressed in CSCs and has been reported to contribute to tumor initiation, progression and metastasis [126]. For example, piR-932 and Mili have been proposed to be positive regulators in the process of breast CSCs. Specifically, Mili and piR-932 promote the methylation of Latexin, which possesses tumor suppressor functions. Methylation of Latexin will silence the Latexin gene and therefore permitting cancer metastasis. Therefore, both piR932 and Mili may serve as potential therapeutic targets for preventing breast cancer metastasis of [127].

Several human Piwi proteins have been shown to be, responsible for CSC self-renewal and cancer metastasis in a wide range of cancer types. Increased expression of Hiwi has been correlated with a poor prognosis for patients with soft-tissue sarcomas (STS). Another human Piwi protein is Hili, and its expression has been correlated with pluripotent genes Oct4 and SOX2 in cancer tissues in colorectal 
cancer [128]. Hiwi also seems to play a key role in proliferation and metastasis of hepatocellular carcinoma (HCC) [129]. Hiwi also may facilitate chemoresistance in cervical cancer [130]. Further investigation on the function of AGO/Piwi proteins in human cancers might help identify additional tumor markers and drug targets [131].

Somatic stem cells. Somatic stem cells (SSCs) are found in unique stem cell niches located at different adult tissues. CSCs are lineage specific, have limited proliferation and differentiation capacity, and are only committed to certain specific cell fates. One example of SSCs is CD34 ${ }^{+}$hematopoietic stem cells (HSCs), which represent probably one of the best characterized SSCs. Hiwi has been identified to be expressed in human hematopoietic progenitor cells, but not in mature blood cells [132]. Miwi2 (Piwil4) is expressed in primitive hematopoietic cells. Interestingly, mice with a triple knockout of Miwi, Mili, and Miwi2, are able to maintain hematopoiesis in long-term [133], indicating their function is not essential for HSCs. Another example of Piwi's function in SSCs is the requirement of Piwi in somatic cyst stem cell, which is essential for early germ cell maintenance. Because of the indispensable role of Piwi in GSCs, Piwi might serve as an important connection between the somatic and germline stem cell lineages [15]. Another example of SSCs is mesenchymal stem cells (MSCs). These SSCs potentially can robustly participate in tissue regeneration and repair [134]. Piwi protein PiwiL2 and associated piRNAs are expressed in bone marrow derived MSCs and may regulate the cell cycle of MSCs [135].

Pluripotent stem cells. Pluripotent stem cells (PSCs) include embryonic stem cells (ESCs) and induced pluripotent stem cells (iPSCs). Three Piwi genes, Miwi, Mili, and Miwi2, have been shown to be highly expressed in ESCs when compared to fibroblasts. However, mice knocking out all three Piwi genes are viable. Female knockout mice are able to breed although male mice are sterile. Miwi encodes a cytoplasmic protein specifically expresses in spermatocytes and spermatids [136]. Miwi2 is a nuclear protein expresses in the embryonic and neonatal stages. Miwi2 may function to control chromatin signatures of mESCs [137]. Furthermore, iPSCs are obtained at comparable efficiency from fibroblasts of triple knockout mice of Miwi/Mili/Miwi2 genes, indicating that at least these three Piwi proteins are dispensable iPSC reprogram process [138]. In human, AGO2 has been revealed to be indispensable for self-renewal and differentiation of ESCs by both siRNA and miRNA pathways through the research on Ago2-deficient ESCs [139]. Moreover, immunoprecipitation of human AGO2 has identified pluripotency-specific miRNAs expressed in both hESCs and iPSCs [32].

Four AGO proteins (AGO1-4) have been identified in mammals. AGO2 is the only one that has endonucleolytic activity. Oocytes from Ago2-deficient mice are able to mature, but have abnormal spindles and chromosomes, which prevent them from being able to cluster [140]. Female mice express Ago2 ${ }^{\mathrm{ADH}}$, a catalytically deficient knock-in allele of Ago2, which lack the function of endo-siRNAs, are infertile due to defects in meiosis I, indicating that catalytic activity of Ago2 is a prerequisite for meiosis in mouse oocytes to complete. Furthermore, some retrotransposon levels have been shown to be upregulated in Ago2 ${ }^{\mathrm{ADH}}$ oocytes [141]. Similar to mammal AGO2, Drosophila ago-2 embryos are defective in chromosome condensation, nuclear kinesis, and spindle apparatus assembly [142]. Therefore, AGO/Piwi protein bound small RNAs (miRNAs, siRNAs and piRNAs) are important players in ESCs through TE silencing for the proper formation of chromosomal structures, as well as gene expression regulation for normal metabolism.

\section{Conclusions}

The AGO protein family binds specific small RNAs in various tissues and influence stem cell properties including self-renewal, proliferation and differentiation, at several levels of gene expression regulation, including transcriptional and posttranscriptional repression, transposon and retro-transposon silencing, chromosomal modification. The relationship between AGO and its interacting proteins in gene regulation needed to be further defined. Construction of the regulation network of AGO-small RNAs-targets from various stem cells would be better revealed the AGO and small RNAs function. Systematic analysis on AGO modifications and regulations in stem cells are 
warranted, which will provide useful clues for stem cell biology and regenerative medicine, as well as for development of therapeutics for cancer patients.

Acknowledgments: This study was in part supported by grants from the National Natural Science Foundation of China (No. 31501320), and the Bureau of Xiangyang City Science and Technology projects (No. (2014) 12-33), the doctoral research fund of Hubei University of Arts and Science (No. 31), and the Foundation of Hubei Educational Committee (No. Q20152601), and the Project for Discipline Groups Construction of Food New-type Industrialization of Hubei University of Arts and Science, Xiangyang, China.

Author Contributions: Lihong Zhai, Lin Wang, Feng Teng, Lanting Zhou, Wenjing Zhang, Juan Xiao, Ying Liu, Wenbin Deng researched the data for the article, provided substantial contributions to discussions of the content, and wrote the article.

Conflicts of Interest: The authors declare no conflict of interest.

\section{References}

1. Carthew, R.W.; Sontheimer, E.J. Origins and mechanisms of miRNAs and siRNAs. Cell 2009, 136, $642-655$. [CrossRef] [PubMed]

2. Farazi, T.A.; Juranek, S.A.; Tuschl, T. The growing catalog of small RNAs and their association with distinct Argonaute/Piwi family members. Development 2008, 135, 1201-1214. [CrossRef] [PubMed]

3. Höck, J.; Meister, G. The Argonaute protein family. Genome Biol. 2008, 9. [CrossRef] [PubMed]

4. Carmell, M.A.; Xuan, Z.; Zhang, M.Q.; Hannon, G.J. The Argonaute family: Tentacles that reach into RNAi, developmental control, stem cell maintenance, and tumorigenesis. Genes Dev. 2002, 16, 2733-2742. [CrossRef] [PubMed]

5. Unhavaithaya, Y.; Hao, Y.; Beyret, E.; Yin, H.; Kuramochi-Miyagawa, S.; Nakano, T.; Lin, H. MILI, a Piwi-interacting RNA-binding protein, is required for germ line stem cell self-renewal and appears to positively regulate translation. J. Biol. Chem. 2009, 284, 6507-6519. [CrossRef] [PubMed]

6. Grochola, L.F.; Greither, T.; Taubert, H.; Moller, P.; Knippschild, U.; Udelnow, A.; Henne-Bruns, D.; Wurl, P. The stem cell-associated Hiwi gene in human adenocarcinoma of the pancreas: Expression and risk of tumour-related death. Br. J. Cancer 2008, 99, 1083-1088. [CrossRef] [PubMed]

7. Lee, J.H.; Engel, W.; Nayernia, K. Stem cell protein Piwil2 modulates expression of murine spermatogonial stem cell expressed genes. Mol. Reprod. Dev. 2006, 73, 173-179. [CrossRef] [PubMed]

8. Bohmert, K.; Camus, I.; Bellini, C.; Bouchez, D.; Caboche, M.; Benning, C. AGO1 defines a novel locus of Arabidopsis controlling leaf development. EMBO J. 1998, 17, 170-180. [CrossRef] [PubMed]

9. Mallory, A.; Vaucheret, H. Form, function, and regulation of ARGONAUTE proteins. Plant Cell 2010, 22, 3879-3889. [CrossRef] [PubMed]

10. Vaucheret, H. Plant Argonautes. Trends Plant Sci. 2008, 13, 350-358. [CrossRef] [PubMed]

11. Meister, G. Argonaute proteins: Functional insights and emerging roles. Nat. Rev. Genet. 2013, 14, 447-459. [CrossRef] [PubMed]

12. Hutvagner, G.; Simard, M.J. Argonaute proteins: Key players in RNA silencing. Nat. Rev. Mol. Cell Biol. 2008, 9, 22-32. [CrossRef] [PubMed]

13. Peters, L.; Meister, G. Argonaute proteins: Mediators of RNA silencing. Mol. Cell 2007, 26, 611-623. [CrossRef] [PubMed]

14. Sasaki, T.; Shiohama, A.; Minoshima, S.; Shimizu, N. Identification of eight members of the Argonaute family in the human genome. Genomics 2003, 82, 323-330. [CrossRef]

15. Gonzalez, J.; Qi, H.; Liu, N.; Lin, H. Piwi is a key regulator of both somatic and germline stem cells in the Drosophila testis. Cell Rep. 2015, 12, 150-161. [CrossRef] [PubMed]

16. Parker, J.S.; Roe, S.M.; Barford, D. Structural insights into mRNA recognition from a Piwi domain-siRNA guide complex. Nature 2005, 434, 663-666. [CrossRef] [PubMed]

17. Ma, J.B.; Yuan, Y.R.; Meister, G.; Pei, Y.; Tuschl, T.; Patel, D.J. Structural basis for $5^{\prime}$-end-specific recognition of guide RNA by the A. fulgidus Piwi protein. Nature 2005, 434, 666-670. [CrossRef] [PubMed]

18. Bamezai, S.; Rawat, V.P.; Buske, C. Concise review: The Piwi-piRNA axis: Pivotal beyond transposon silencing. Stem Cells 2012, 30, 2603-2611. [CrossRef] [PubMed]

19. Song, J.J.; Smith, S.K.; Hannon, G.J.; Joshua-Tor, L. Crystal structure of Argonaute and its implications for RISC slicer activity. Science 2004, 305, 1434-1437. [CrossRef] [PubMed] 
20. Rivas, F.V.; Tolia, N.H.; Song, J.-J.; Aragon, J.P.; Liu, J.; Hannon, G.J.; Joshua-Tor, L. Purified Argonaute2 and an siRNA form recombinant human RISC. Nat. Struct. Mol. Biol. 2005, 12, 340-349. [CrossRef] [PubMed]

21. Nakanishi, K.; Weinberg, D.E.; Bartel, D.P.; Patel, D.J. Structure of yeast Argonaute with guide RNA. Nature 2012, 486, 368-374. [CrossRef] [PubMed]

22. Meister, G.; Landthaler, M.; Patkaniowska, A.; Dorsett, Y.; Teng, G.; Tuschl, T. Human Argonaute2 mediates RNA cleavage targeted by miRNAs and siRNAs. Mol. Cell 2004, 15, 185-197. [CrossRef] [PubMed]

23. Schirle, N.T.; MacRae, I.J. The crystal structure of human Argonaute2. Science 2012, 336, 1037-1040. [CrossRef] [PubMed]

24. Zhang, X.; Niu, D.; Carbonell, A.; Wang, A.; Lee, A.; Tun, V.; Wang, Z.; Carrington, J.C.; Chang, C.E.; Jin, H. ARGONAUTE Piwi domain and microRNA duplex structure regulate small RNA sorting in Arabidopsis. Nat. Commun. 2014, 5. [CrossRef] [PubMed]

25. Li, Y.; Tang, W.; Zhang, L.R.; Zhang, C.Y. FMRP regulates miR196a-mediated repression of HOXB8 via interaction with the AGO2 MID domain. Mol. Biosyst. 2014, 10, 1757-1764. [CrossRef] [PubMed]

26. Schirle, N.T.; Sheu-Gruttadauria, J.; MacRae, I.J. Structural basis for microRNA targeting. Science 2014, 346, 608-613. [CrossRef] [PubMed]

27. Schirle, N.T.; Sheu-Gruttadauria, J.; Chandradoss, S.D.; Joo, C.; MacRae, I.J. Water-mediated recognition of t1-adenosine anchors Argonaute2 to microRNA targets. eLife 2015, 4. [CrossRef] [PubMed]

28. Rashid, U.J.; Paterok, D.; Koglin, A.; Gohlke, H.; Piehler, J.; Chen, J.C. Structure of Aquifex aeolicus argonaute highlights conformational flexibility of the PAZ domain as a potential regulator of RNA-induced silencing complex function. J. Biol. Chem. 2007, 282, 13824-13832. [CrossRef] [PubMed]

29. Allo, M.; Agirre, E.; Bessonov, S.; Bertucci, P.; Gomez Acuna, L.; Buggiano, V.; Bellora, N.; Singh, B.; Petrillo, E.; Blaustein, M.; et al. Argonaute-1 binds transcriptional enhancers and controls constitutive and alternative splicing in human cells. Proc. Natl. Acad. Sci. USA 2014, 111, 15622-15629. [CrossRef] [PubMed]

30. Burroughs, A.M.; Ando, Y.; de Hoon, M.J.; Tomaru, Y.; Suzuki, H.; Hayashizaki, Y.; Daub, C.O. Deep-sequencing of human Argonaute-associated small RNAs provides insight into miRNA sorting and reveals Argonaute association with RNA fragments of diverse origin. RNA Biol. 2011, 8, 158-177. [CrossRef] [PubMed]

31. Janowski, B.A.; Huffman, K.E.; Schwartz, J.C.; Ram, R.; Nordsell, R.; Shames, D.S.; Minna, J.D.; Corey, D.R. Involvement of AGO1 and AGO2 in mammalian transcriptional silencing. Nat. Struct. Mol. Biol. 2006, 13, 787-792. [CrossRef] [PubMed]

32. Goff, L.A.; Davila, J.; Swerdel, M.R.; Moore, J.C.; Cohen, R.I.; Wu, H.; Sun, Y.E.; Hart, R.P. Ago2 immunoprecipitation identifies predicted microRNAs in human embryonic stem cells and neural precursors. PLoS ONE 2009, 4, e7192. [CrossRef] [PubMed]

33. Zhang, K.; Lu, Y.; Yang, P.; Li, C.; Sun, H.; Tao, D.; Liu, Y.; Zhang, S.; Ma, Y. Hili inhibits TGF-beta signaling by interacting with Hsp90 and promoting TbetaR degradation. PLOS ONE 2012, 7, e41973.

34. Keam, S.P.; Young, P.E.; McCorkindale, A.L.; Dang, T.H.; Clancy, J.L.; Humphreys, D.T.; Preiss, T.; Hutvagner, G.; Martin, D.I.; Cropley, J.E.; et al. The human Piwi protein Hiwi2 associates with tRNA-derived piRNAs in somatic cells. Nucleic Acids Res. 2014, 42, 8984-8995. [CrossRef] [PubMed]

35. Ghildiyal, M.; Xu, J.; Seitz, H.; Weng, Z.; Zamore, P.D. Sorting of Drosophila small silencing RNAs partitions microRNA* strands into the RNA interference pathway. RNA 2010, 16, 43-56. [CrossRef] [PubMed]

36. Okamura, K.; Ishizuka, A.; Siomi, H.; Siomi, M.C. Distinct roles for Argonaute proteins in small RNA-directed RNA cleavage pathways. Genes Dev. 2004, 18, 1655-1666. [CrossRef] [PubMed]

37. Ameres, S.L.; Hung, J.H.; Xu, J.; Weng, Z.; Zamore, P.D. Target RNA-directed tailing and trimming purifies the sorting of endo-siRNAs between the two Drosophila Argonaute proteins. RNA 2011, 17, 54-63. [CrossRef] [PubMed]

38. Hammond, S.M.; Boettcher, S.; Caudy, A.A.; Kobayashi, R.; Hannon, G.J. Argonaute2, a link between genetic and biochemical analyses of RNAi. Science 2001, 293, 1146-1150. [CrossRef] [PubMed]

39. Mani, S.R.; Megosh, H.; Lin, H. Piwi proteins are essential for early Drosophila embryogenesis. Dev. Biol. 2014, 385, 340-349. [CrossRef] [PubMed]

40. Kalmykova, A.I.; Klenov, M.S.; Gvozdev, V.A. Argonaute protein Piwi controls mobilization of retrotransposons in the Drosophila male germline. Nucleic Acids Res. 2005, 33, 2052-2059. [CrossRef] [PubMed] 
41. Brennecke, J.; Aravin, A.A.; Stark, A.; Dus, M.; Kellis, M.; Sachidanandam, R.; Hannon, G.J. Discrete small RNA-generating loci as master regulators of transposon activity in Drosophila. Cell 2007, 128, 1089-1103. [CrossRef] [PubMed]

42. Vagin, V.V.; Sigova, A.; Li, C.; Seitz, H.; Gvozdev, V.; Zamore, P.D. A distinct small RNA pathway silences selfish genetic elements in the germline. Science 2006, 313, 320-324. [CrossRef] [PubMed]

43. Saito, K.; Nishida, K.M.; Mori, T.; Kawamura, Y.; Miyoshi, K.; Nagami, T.; Siomi, H.; Siomi, M.C. Specific association of Piwi with rasiRNAs derived from retrotransposon and heterochromatic regions in the Drosophila genome. Genes Dev. 2006, 20, 2214-2222. [CrossRef] [PubMed]

44. Vaucheret, H.; Vazquez, F.; Crété, P.; Bartel, D.P. The action of ARGONAUTE1 in the miRNA pathway and its regulation by the miRNA pathway are crucial for plant development. Genes Dev. 2004, 18, 1187-1197. [CrossRef] [PubMed]

45. Dzianott, A.; Sztuba-Solinska, J.; Bujarski, J.J. Mutations in the antiviral RNAi defense pathway modify Brome mosaic virus RNA recombinant profiles. MPMI 2012, 25, 97-106. [CrossRef] [PubMed]

46. Oliver, C.; Santos, J.L.; Pradillo, M. On the role of some ARGONAUTE proteins in meiosis and DNA repair in Arabidopsis thaliana. Front. Plant Sci. 2014, 5. [CrossRef] [PubMed]

47. Takeda, A.; Iwasaki, S.; Watanabe, T.; Utsumi, M.; Watanabe, Y. The mechanism selecting the guide strand from small RNA duplexes is different among argonaute proteins. Plant Cell Physiol. 2008, 49, 493-500. [CrossRef] [PubMed]

48. Jaubert, M.; Bhattacharjee, S.; Mello, A.F.; Perry, K.L.; Moffett, P. ARGONAUTE2 mediates RNA-silencing antiviral defenses against Potato virus $X$ in Arabidopsis. Plant Physiol. 2011, 156, 1556-1564. [CrossRef] [PubMed]

49. Havecker, E.R.; Wallbridge, L.M.; Hardcastle, T.J.; Bush, M.S.; Kelly, K.A.; Dunn, R.M.; Schwach, F.; Doonan, J.H.; Baulcombe, D.C. The Arabidopsis RNA-directed DNA methylation argonautes functionally diverge based on their expression and interaction with target loci. Plant Cell 2010, 22, 321-334. [CrossRef] [PubMed]

50. Matzke, M.A.; Mosher, R.A. RNA-directed DNA methylation: An epigenetic pathway of increasing complexity. Nat. Rev. Genet. 2014, 15, 394-408. [CrossRef] [PubMed]

51. Brosseau, C.; Moffett, P. Functional and genetic analysis identify a role for arabidopsis ARGONAUTE5 in antiviral RNA silencing. Plant Cell 2015, 27, 1742-1754. [CrossRef] [PubMed]

52. Mi, S.; Cai, T.; Hu, Y.; Chen, Y.; Hodges, E.; Ni, F.; Wu, L.; Li, S.; Zhou, H.; Long, C.; et al. Sorting of small RNAs into Arabidopsis argonaute complexes is directed by the $5^{\prime}$ terminal nucleotide. Cell 2008, 133, 116-127. [CrossRef] [PubMed]

53. Tucker, M.R.; Okada, T.; Hu, Y.; Scholefield, A.; Taylor, J.M.; Koltunow, A.M. Somatic small RNA pathways promote the mitotic events of megagametogenesis during female reproductive development in Arabidopsis. Development 2012, 139, 1399-1404. [CrossRef] [PubMed]

54. Zheng, X.; Zhu, J.; Kapoor, A.; Zhu, J.-K. Role of Arabidopsis AGO6 in siRNA accumulation, DNA methylation and transcriptional gene silencing. EMBO J. 2007, 26, 1691-1701. [CrossRef] [PubMed]

55. Eun, C.; Lorkovic, Z.J.; Naumann, U.; Long, Q.; Havecker, E.R.; Simon, S.A.; Meyers, B.C.; Matzke, A.J.; Matzke, M. AGO6 functions in RNA-mediated transcriptional gene silencing in shoot and root meristems in Arabidopsis thaliana. PLoS ONE 2011, 6, e25730. [CrossRef] [PubMed]

56. McCue, A.D.; Panda, K.; Nuthikattu, S.; Choudury, S.G.; Thomas, E.N.; Slotkin, R.K. ARGONAUTE 6 bridges transposable element mRNA-derived siRNAs to the establishment of DNA methylation. EMBO J. 2015, 34, 20-35. [CrossRef] [PubMed]

57. Hunter, C.; Sun, H.; Poethig, R. The Arabidopsis heterochronic gene ZIPPY is an ARGONAUTE family member. Curr. Biol. 2003, 13, 1734-1739. [CrossRef] [PubMed]

58. Zhu, H.; Hu, F.; Wang, R.; Zhou, X.; Sze, S.-H.H.; Liou, L.W.W.; Barefoot, A.; Dickman, M.; Zhang, X. Arabidopsis Argonaute10 specifically sequesters miR166/165 to regulate shoot apical meristem development. Cell 2011, 145, 242-256. [CrossRef] [PubMed]

59. Moussian, B.; Schoof, H.; Haecker, A.; Jürgens, G.; Laux, T. Role of the ZWILLE gene in the regulation of central shoot meristem cell fate during Arabidopsis embryogenesis. EMBO J. 1998, 17, 1799-1809. [CrossRef] [PubMed] 
60. Lynn, K.; Fernandez, A.; Aida, M.; Sedbrook, J.; Tasaka, M.; Masson, P.; Barton, M.K. The PINHEAD/ZWILLE gene acts pleiotropically in Arabidopsis development and has overlapping functions with the ARGONAUTE1 gene. Development 1999, 126, 469-481. [PubMed]

61. Liu, Q.; Yao, X.; Pi, L.; Wang, H.; Cui, X.; Huang, H. The ARGONAUTE10 gene modulates shoot apical meristem maintenance and establishment of leaf polarity by repressing miR165/166 in Arabidopsis. Plant J. Cell Mol. Biol. 2009, 58, 27-40. [CrossRef] [PubMed]

62. Manavella, P.A.; Weigel, D.; Wu, L. Argonaute10 as a miRNA Locker. Cell 2011, 145, 173-174. [CrossRef] [PubMed]

63. Ji, L.; Liu, X.; Yan, J.; Wang, W.; Yumul, R.E.; Kim, Y.J.; Dinh, T.T.; Liu, J.; Cui, X.; Zheng, B. ARGONAUTE10 and ARGONAUTE1 regulate the termination of floral stem cells through two microRNAs in Arabidopsis. PLoS Genet. 2011, 7, e1001358. [CrossRef] [PubMed]

64. Wu, L.; Zhang, Q.; Zhou, H.; Ni, F.; Wu, X.; Qi, Y. Rice microRNA effector complexes and targets. Plant Cell Online 2009, 21, 3421-3435. [CrossRef] [PubMed]

65. Nonomura, K.-I.; Morohoshi, A.; Nakano, M.; Eiguchi, M.; Miyao, A.; Hirochika, H.; Kurata, N. A germ cell-specific gene of the Argonaute family is essential for the progression of premeiotic mitosis and meiosis during sporogenesis in rice. Plant Cell Online 2007, 19, 2583-2594. [CrossRef] [PubMed]

66. Komiya, R.; Ohyanagi, H.; Niihama, M.; Watanabe, T.; Nakano, M.; Kurata, N.; Nonomura, K. Rice germline-specific Argonaute MEL1 protein binds to phasiRNAs generated from more than 700 lincRNAs. Plant J. Cell Mol. Biol. 2014, 78, 385-397. [CrossRef] [PubMed]

67. Shi, Z.; Wang, J.; Wan, X.; Shen, G.; Wang, X.; Zhang, J. Over-expression of rice OsAGO7 gene induces upward curling of the leaf blade that enhanced erect-leaf habit. Planta 2007, 226, 99-108. [CrossRef] [PubMed]

68. Nishimura, A.; Ito, M.; Kamiya, N.; Sato, Y.; Matsuoka, M. OsPNH1 regulates leaf development and maintenance of the shoot apical meristem in rice. Plant J. Cell Mol. Biol. 2002, 30, 189-201. [CrossRef]

69. Wu, J.; Yang, Z.; Wang, Y.; Zheng, L.; Ye, R.; Ji, Y.; Zhao, S.; Ji, S.; Liu, R.; Xu, L.; et al. Viral-inducible Argonaute18 confers broad-spectrum virus resistance in rice by sequestering a host microRNA. eLife 2015, 4. [CrossRef] [PubMed]

70. Douglas, R.N.; Wiley, D.; Sarkar, A.; Springer, N.; Timmermans, M.C.; Scanlon, M.J. ragged seedling2 encodes an ARGONAUTE7-like protein required for mediolateral expansion, but not dorsiventrality, of maize leaves. Plant Cell Online 2010, 22, 1441-1451. [CrossRef] [PubMed]

71. Singh, M.; Goel, S.; Meeley, R.B.; Dantec, C.; Parrinello, H.; Michaud, C.; Leblanc, O.; Grimanelli, D. Production of viable gametes without meiosis in maize deficient for an ARGONAUTE protein. Plant Cell Online 2011, 23, 443-458. [CrossRef] [PubMed]

72. Zhai, L.; Sun, W.; Zhang, K.; Jia, H.; Liu, L.; Liu, Z.; Teng, F.; Zhang, Z. Identification and characterization of Argonaute gene family and meiosis-enriched Argonaute during sporogenesis in maize. J. Integr. Plant Biol. 2014, 56, 1042-1052. [CrossRef] [PubMed]

73. Zhang, H.; Xia, R.; Meyers, B.C.; Walbot, V. Evolution, functions, and mysteries of plant ARGONAUTE proteins. Curr. Opin. Plant Biol. 2015, 27, 84-90. [CrossRef] [PubMed]

74. Ender, C.; Meister, G. Argonaute proteins at a glance. J. Cell Sci. 2010, 123, 1819-1823. [CrossRef] [PubMed]

75. Kobayashi, H.; Tomari, Y. RISC assembly: Coordination between small RNAs and Argonaute proteins. Biochim. Biophys. Acta 2016, 1859, 71-81. [CrossRef] [PubMed]

76. Hannon, G.J. RNA interference. Nature 2002, 418, 244-251. [CrossRef] [PubMed]

77. Tomari, Y.; Zamore, P.D. Perspective: Machines for RNAi. Genes Dev. 2005, 19, 517-529. [CrossRef] [PubMed]

78. Lim, R.S.; Kai, T. A piece of the pi(e): The diverse roles of animal piRNAs and their Piwi partners. Semin. Cell Dev. Biol. 2015, 47-48, 17-31. [CrossRef] [PubMed]

79. Nishida, K.M.; Saito, K.; Mori, T.; Kawamura, Y.; Nagami-Okada, T.; Inagaki, S.; Siomi, H.; Siomi, M.C. Gene silencing mechanisms mediated by Aubergine piRNA complexes in Drosophila male gonad. RNA 2007, 13, 1911-1922. [CrossRef] [PubMed]

80. Barckmann, B.; Pierson, S.; Dufourt, J.; Papin, C.; Armenise, C.; Port, F.; Grentzinger, T.; Chambeyron, S.; Baronian, G.; Desvignes, J.P.; et al. Aubergine iCLIP reveals piRNA-dependent decay of mRNAs involved in germ cell development in the early embryo. Cell Rep. 2015, 12, 1205-1216. [CrossRef] [PubMed]

81. Klenov, M.S.; Lavrov, S.A.; Stolyarenko, A.D.; Ryazansky, S.S.; Aravin, A.A.; Tuschl, T.; Gvozdev, V.A. Repeat-associated siRNAs cause chromatin silencing of retrotransposons in the Drosophila melanogaster germline. Nucleic Acids Res. 2007, 35, 5430-5438. [CrossRef] [PubMed] 
82. Toth, K.F.; Pezic, D.; Stuwe, E.; Webster, A. The piRNA pathway guards the germline genome against transposable elements. Adv. Exp. Med. Biol. 2016, 886, 51-77. [PubMed]

83. Senti, K.A.; Jurczak, D.; Sachidanandam, R.; Brennecke, J. piRNA-guided slicing of transposon transcripts enforces their transcriptional silencing via specifying the nuclear piRNA repertoire. Genes Dev. 2015, 29, 1747-1762. [CrossRef] [PubMed]

84. Peng, L.; Song, L.; Liu, C.; Lv, X.; Li, X.; Jie, J.; Zhao, D.; Li, D. piR-55490 inhibits the growth of lung carcinoma by suppressing mTOR signaling. Tumour Biol. 2015, 1-8. [CrossRef] [PubMed]

85. Chen, M.; Bao, H.; Wu, Q.; Wang, Y. Transcriptome-wide identification of miRNA targets under nitrogen deficiency in populus tomentosa using degradome sequencing. Int. J. Mol. Sci. 2015, 16, 13937-13958. [CrossRef] [PubMed]

86. Xu, T.; Wang, Y.; Liu, X.; Lv, S.; Feng, C.; Qi, M.; Li, T. Small RNA and degradome sequencing reveals microRNAs and their targets involved in tomato pedicel abscission. Planta 2015, 242, 963-984. [CrossRef] [PubMed]

87. Zhai, L.; Liu, Z.; Zou, X.; Jiang, Y.; Qiu, F.; Zheng, Y.; Zhang, Z. Genome-wide identification and analysis of microRNA responding to long-term waterlogging in crown roots of maize seedlings. Physiol. Plant. 2013, 147, 181-193. [CrossRef] [PubMed]

88. Chi, S.W.; Zang, J.B.; Mele, A.; Darnell, R.B. Argonaute HITS-CLIP decodes microRNA-mRNA interaction maps. Nature 2009, 460, 479-486. [CrossRef] [PubMed]

89. Hsu, S.D.; Huang, H.Y.; Chou, C.H.; Sun, Y.M.; Hsu, M.T.; Tsou, A.P. Integrated analyses to reconstruct microRNA-mediated regulatory networks in mouse liver using high-throughput profiling. BMC Genom. 2015, 16. [CrossRef] [PubMed]

90. Haecker, I.; Renne, R. HITS-CLIP and PAR-CLIP advance viral miRNA targetome analysis. Crit. Rev. Eukaryot. Gene Expr. 2014, 24, 101-116. [CrossRef] [PubMed]

91. Vourekas, A.; Mourelatos, Z. HITS-CLIP (CLIP-Seq) for mouse Piwi proteins. Methods Mol. Biol. 2014, 1093, 73-95. [PubMed]

92. Montgomery, T.A.; Howell, M.D.; Cuperus, J.T.; Li, D.; Hansen, J.E.; Alexander, A.L.; Chapman, E.J.; Fahlgren, N.; Allen, E.; Carrington, J.C. Specificity of ARGONAUTE7-miR390 interaction and dual functionality in TAS3 trans-acting siRNA formation. Cell 2008, 133, 128-141. [CrossRef] [PubMed]

93. Durán-Figueroa, N.; Vielle-Calzada, J.-P. ARGONAUTE9-dependent silencing of transposable elements in pericentromeric regions of Arabidopsis. Plant Signal. Behav. 2010, 5, 1476-1479. [CrossRef] [PubMed]

94. Girard, A.; Sachidanandam, R.; Hannon, G.J.; Carmell, M.A. A germline-specific class of small RNAs binds mammalian Piwi proteins. Nature 2006, 442, 199-202. [CrossRef] [PubMed]

95. Aravin, A.; Gaidatzis, D.; Pfeffer, S.; Lagos-Quintana, M.; Landgraf, P.; Iovino, N.; Morris, P.; Brownstein, M.J.; Kuramochi-Miyagawa, S.; Nakano, T.; et al. A novel class of small RNAs bind to MILI protein in mouse testes. Nature 2006, 442, 203-207. [CrossRef] [PubMed]

96. Beitzinger, M.; Peters, L.; Zhu, J.Y.; Kremmer, E.; Meister, G. Identification of human microRNA targets from isolated argonaute protein complexes. RNA Biol. 2007, 4, 76-84. [CrossRef] [PubMed]

97. Hafner, M.; Landthaler, M.; Burger, L.; Khorshid, M.; Hausser, J.; Berninger, P.; Rothballer, A.; Ascano, M., Jr.; Jungkamp, A.-C.; Munschauer, M. Transcriptome-wide identification of RNA-binding protein and microRNA target sites by PAR-CLIP. Cell 2010, 141, 129-141. [CrossRef] [PubMed]

98. Zhang, C.; Darnell, R.B. Mapping in vivo protein-RNA interactions at single-nucleotide resolution from HITS-CLIP data. Nat. Biotechnol. 2011, 29, 607-614. [CrossRef] [PubMed]

99. Leung, A.K.; Young, A.G.; Bhutkar, A.; Zheng, G.X.; Bosson, A.D.; Nielsen, C.B.; Sharp, P.A. Genome-wide identification of Ago2 binding sites from mouse embryonic stem cells with and without mature microRNAs. Nat. Struct. Mol. Biol. 2011, 18, 237-244. [CrossRef] [PubMed]

100. Clark, P.M.; Loher, P.; Quann, K.; Brody, J.; Londin, E.R.; Rigoutsos, I. Argonaute CLIP-Seq reveals miRNA targetome diversity across tissue types. Sci. Rep. 2014, 4. [CrossRef] [PubMed]

101. Pfaff, J.; Hennig, J.; Herzog, F.; Aebersold, R.; Sattler, M.; Niessing, D.; Meister, G. Structural features of Argonaute-GW182 protein interactions. Proc. Natl. Acad. Sci. USA 2013, 110, E3770-E3779. [CrossRef] [PubMed]

102. Huntzinger, E.; Izaurralde, E. Gene silencing by microRNAs: contributions of translational repression and mRNA decay. Nat. Rev. Genet. 2011, 12, 99-110. [CrossRef] [PubMed] 
103. Yao, B.; Li, S.; Chan, E.K. Function of GW182 and GW bodies in siRNA and miRNA pathways. Adv. Exp. Med. Biol. 2013, 768, 71-96. [PubMed]

104. Braun, J.E.; Huntzinger, E.; Izaurralde, E. The role of GW182 proteins in miRNA-mediated gene silencing. Adv. Exp. Med. Biol. 2013, 768, 147-163. [PubMed]

105. Pfaff, J.; Meister, G. Argonaute and GW182 proteins: An effective alliance in gene silencing. Biochem. Soc. Trans. 2013, 41, 855-860. [CrossRef] [PubMed]

106. Miles, W.O.; Tschop, K.; Herr, A.; Ji, J.Y.; Dyson, N.J. Pumilio facilitates miRNA regulation of the E2F3 oncogene. Genes Dev. 2012, 26, 356-368. [CrossRef] [PubMed]

107. Weinmann, L.; Hock, J.; Ivacevic, T.; Ohrt, T.; Mutze, J.; Schwille, P.; Kremmer, E.; Benes, V.; Urlaub, H.; Meister, G. Importin 8 is a gene silencing factor that targets argonaute proteins to distinct mRNAs. Cell 2009, 136, 496-507. [CrossRef] [PubMed]

108. Jin, H.; Suh, M.R.; Han, J.; Yeom, K.H.; Lee, Y.; Heo, I.; Ha, M.; Hyun, S.; Kim, V.N. Human UPF1 participates in small RNA-induced mRNA downregulation. Mol. Cell. Biol. 2009, 29, 5789-5799. [CrossRef] [PubMed]

109. Su, H.; Meng, S.; Lu, Y.; Trombly, M.I.; Chen, J.; Lin, C.; Turk, A.; Wang, X. Mammalian hyperplastic discs homolog EDD regulates miRNA-mediated gene silencing. Mol. Cell 2011, 43, 97-109. [CrossRef] [PubMed]

110. Sienski, G.; Batki, J.; Senti, K.A.; Donertas, D.; Tirian, L.; Meixner, K.; Brennecke, J. Silencio/CG9754 connects the Piwi-piRNA complex to the cellular heterochromatin machinery. Genes Dev. 2015, 29, 2258-2271. [CrossRef] [PubMed]

111. Leonov, G.; Shah, K.; Yee, D.; Timmis, J.; Sharp, T.V.; Lagos, D. Suppression of AGO2 by miR-132 as a determinant of miRNA-mediated silencing in human primary endothelial cells. Int. J. Biochem. Cell Biol. 2015, 69, 75-84. [CrossRef] [PubMed]

112. Guo, J.; Lv, J.; Liu, M.; Tang, H. miR-346 Up-regulates Argonaute 2 (AGO2) protein expression to augment the activity of other microRNAs (miRNAs) and contributes to cervical cancer cell malignancy. J. Biol. Chem. 2015, 290, 30342-30350. [PubMed]

113. Takahashi, K.; Yamanaka, S. Induction of pluripotent stem cells from mouse embryonic and adult fibroblast cultures by defined factors. Cell 2006, 126, 663-676. [CrossRef] [PubMed]

114. Cox, D.N.; Chao, A.; Baker, J.; Chang, L.; Qiao, D.; Lin, H. A novel class of evolutionarily conserved genes defined by Piwi are essential for stem cell self-renewal. Genes Dev. 1998, 12, 3715-3727. [CrossRef] [PubMed]

115. Baumberger, N.; Baulcombe, D. Arabidopsis ARGONAUTE1 is an RNA Slicer that selectively recruits microRNAs and short interfering RNAs. Proc. Natl. Acad. Sci. USA 2005, 102, 11928-11933. [CrossRef] [PubMed]

116. Mallory, A.C.; Hinze, A.; Tucker, M.R.; Bouche, N.; Gasciolli, V.; Elmayan, T.; Lauressergues, D.; Jauvion, V.; Vaucheret, H.; Laux, T. Redundant and specific roles of the ARGONAUTE proteins AGO1 and ZLL in development and small RNA-directed gene silencing. PLoS Genet. 2009, 5, e1000646. [CrossRef] [PubMed]

117. Szakmary, A.; Cox, D.N.; Wang, Z.; Lin, H. Regulatory relationship among Piwi, pumilio, and bag-of-marbles in Drosophila germline stem cell self-renewal and differentiation. Curr. Biol. 2005, 15, 171-178. [CrossRef] [PubMed]

118. Jin, Z.; Flynt, A.S.; Lai, E.C. Drosophila Piwi mutants exhibit germline stem cell tumors that are sustained by elevated Dpp signaling. Curr. Biol. 2013, 23, 1442-1448. [CrossRef] [PubMed]

119. Ishizu, H.; Siomi, H.; Siomi, M.C. Biology of Piwi-interacting RNAs: New insights into biogenesis and function inside and outside of germlines. Genes Dev. 2012, 26, 2361-2373. [CrossRef] [PubMed]

120. Klenov, M.S.; Sokolova, O.A.; Yakushev, E.Y.; Stolyarenko, A.D.; Mikhaleva, E.A.; Lavrov, S.A.; Gvozdev, V.A. Separation of stem cell maintenance and transposon silencing functions of Piwi protein. Proc. Natl. Acad. Sci. USA 2011, 108, 18760-18765. [CrossRef] [PubMed]

121. Ma, X.; Wang, S.; Do, T.; Song, X.; Inaba, M.; Nishimoto, Y.; Liu, L.; Gao, Y.; Mao, Y.; Li, H.; et al. Piwi is required in multiple cell types to control germline stem cell lineage development in the Drosophila ovary. PLoS ONE 2014, 9, e90267. [CrossRef] [PubMed]

122. Yang, L.; Chen, D.; Duan, R.; Xia, L.; Wang, J.; Qurashi, A.; Jin, P. Argonaute 1 regulates the fate of germline stem cells in Drosophila. Development 2007, 134, 4265-4272. [CrossRef] [PubMed]

123. Li, C.; Vagin, V.V.; Lee, S.; Xu, J.; Ma, S.; Xi, H.; Seitz, H.; Horwich, M.D.; Syrzycka, M.; Honda, B.M.; et al . Collapse of germline piRNAs in the absence of Argonaute3 reveals somatic piRNAs in flies. Cell 2009, 137, 509-521. [CrossRef] [PubMed] 
124. Visvader, J.E.; Lindeman, G.J. Cancer stem cells in solid tumours: Accumulating evidence and unresolved questions. Nat. Rev. Cancer 2008, 8, 755-768. [CrossRef] [PubMed]

125. Liu, J.J.; Shen, R.; Chen, L.; Ye, Y.; He, G.; Hua, K.; Jarjoura, D.; Nakano, T.; Ramesh, G.K.; Shapiro, C.L.; et al . Piwil2 is expressed in various stages of breast cancers and has the potential to be used as a novel biomarker. Int. J. Clin. Exp. Pathol. 2010, 3, 328-337. [PubMed]

126. Shahali, M.; Kabir-Salmani, M.; Nayernia, K.; Soleimanpour-Lichaei, H.R.; Vasei, M.; Mowla, S.J.; Ranaie, E.; Shakibaie, M.; Modaresi, M.H. A novel in vitro model for cancer stem cell culture using ectopically expressed piwil2 stable cell line. Cell J. 2013, 15, 250-257. [PubMed]

127. Zhang, H.; Ren, Y.; Xu, H.; Pang, D.; Duan, C.; Liu, C. The expression of stem cell protein Piwil2 and piR-932 in breast cancer. Surg. Oncol. 2013, 22, 217-223. [CrossRef] [PubMed]

128. Litwin, M.; Dubis, J.; Arczynska, K.; Piotrowska, A.; Frydlewicz, A.; Karczewski, M.; Dziegiel, P.; Witkiewicz, W. Correlation of Hiwi and Hili expression with cancer stem cell markers in colorectal cancer. Anticancer Res. 2015, 35, 3317-3324. [PubMed]

129. Zhao, Y.M.; Zhou, J.M.; Wang, L.R.; He, H.W.; Wang, X.L.; Tao, Z.H.; Sun, H.C.; Wu, W.Z.; Fan, J.; Tang, Z.Y.; et al. Hiwi is associated with prognosis in patients with hepatocellular carcinoma after curative resection. Cancer 2012, 118, 2708-2717. [CrossRef] [PubMed]

130. Liu, W.; Gao, Q.; Chen, K.; Xue, X.; Li, M.; Chen, Q.; Zhu, G.; Gao, Y. Hiwi facilitates chemoresistance as a cancer stem cell marker in cervical cancer. Oncol. Rep. 2014, 32, 1853-1860. [CrossRef] [PubMed]

131. Taubert, H.; Greither, T.; Kaushal, D.; Wurl, P.; Bache, M.; Bartel, F.; Kehlen, A.; Lautenschlager, C.; Harris, L.; Kraemer, K.; et al. Expression of the stem cell self-renewal gene Hiwi and risk of tumour-related death in patients with soft-tissue sarcoma. Oncogene 2007, 26, 1098-1100. [CrossRef] [PubMed]

132. Sharma, A.K.; Nelson, M.C.; Brandt, J.E.; Wessman, M.; Mahmud, N.; Weller, K.P.; Hoffman, R. Human $\mathrm{CD}_{4}{ }^{+}$stem cells express the Hiwi gene, a human homologue of the Drosophila gene Piwi. Blood 2001, 97, 426-434. [CrossRef] [PubMed]

133. Nolde, M.J.; Cheng, E.C.; Guo, S.; Lin, H. Piwi genes are dispensable for normal hematopoiesis in mice. PLoS ONE 2013, 8, e71950. [CrossRef] [PubMed]

134. Zou, Z.; Zhang, Y.; Hao, L.; Wang, F.; Liu, D.; Su, Y.; Sun, H. More insight into mesenchymal stem cells and their effects inside the body. Expert Opin. Biol. Ther. 2010, 10, 215-230. [CrossRef] [PubMed]

135. Wu, Q.; Ma, Q.; Shehadeh, L.A.; Wilson, A.; Xia, L.; Yu, H.; Webster, K.A. Expression of the Argonaute protein PiwiL2 and piRNAs in adult mouse mesenchymal stem cells. Biochem. Biophys. Res. Commun. 2010, 396, 915-920. [CrossRef] [PubMed]

136. Deng, W.; Lin, H. Miwi, a murine homolog of Piwi, encodes a cytoplasmic protein essential for spermatogenesis. Dev. Cell 2002, 2, 819-830. [CrossRef]

137. Aravin, A.A.; Sachidanandam, R.; Bourc'his, D.; Schaefer, C.; Pezic, D.; Toth, K.F.; Bestor, T.; Hannon, G.J. A piRNA pathway primed by individual transposons is linked to de novo DNA methylation in mice. Mol. Cell 2008, 31, 785-799. [CrossRef] [PubMed]

138. Cheng, E.C.; Kang, D.; Wang, Z.; Lin, H. Piwi proteins are dispensable for mouse somatic development and reprogramming of fibroblasts into pluripotent stem cells. PLoS ONE 2014, 9, e97821. [CrossRef] [PubMed]

139. Shekar, P.C.; Naim, A.; Sarathi, D.P.; Kumar, S. Argonaute-2-null embryonic stem cells are retarded in self-renewal and differentiation. J. Biosci. 2011, 36, 649-657. [CrossRef] [PubMed]

140. Kaneda, M.; Tang, F.; O'Carroll, D.; Lao, K.; Surani, M.A. Essential role for Argonaute2 protein in mouse oogenesis. Epigenet. Chromatin. 2009, 2. [CrossRef] [PubMed]

141. Stein, P.; Rozhkov, N.V.; Li, F.; Cardenas, F.L.; Davydenko, O.; Vandivier, L.E.; Gregory, B.D.; Hannon, G.J.; Schultz, R.M. Essential Role for endogenous siRNAs during meiosis in mouse oocytes. PLoS Genet. 2015, 11, e1005013. [CrossRef] [PubMed]

142. Deshpande, G.; Calhoun, G.; Schedl, P. Drosophila argonaute-2 is required early in embryogenesis for the assembly of centric/centromeric heterochromatin, nuclear division, nuclear migration, and germ-cell formation. Genes Dev. 2005, 19, 1680-1685. [CrossRef] [PubMed]

(C) 2016 by the authors; licensee MDPI, Basel, Switzerland. This article is an open access article distributed under the terms and conditions of the Creative Commons by Attribution (CC-BY) license (http:/ / creativecommons.org/licenses/by/4.0/). 